\title{
A magyar gyermek- és népdalfeldolgozások Bartók Béla: Gyermekeknek sorozatában
}

\author{
Szesztay Zsuzsa \\ Eötvös Loránd Tudományegyetem Tanitó- és Óvóképzö Kar Ének-zenei Tanszék
}

\begin{abstract}
Absztrakt
A tanulmány a 20. század egyik legjelentősebb magyar zeneszerzője, népzenetudósa és zongoraművésze, Bartók Béla (1881-1945) születésének 140. évfordulója előtt tiszteleg. A magyar gyermek- és népdalfeldolgozások különleges inspirációs forrást jelentettek Bartók 1908 és 1911 között keletkezett korai zongoramüveiben. Egyik legjelentősebb müve az 1908-1909-ben készült négy füzetből álló Gyermekeknek címü sorozat. A zongoraciklus, melyet a zongorista- és zenepedagógusi tevékenységet is folytató Bartók kifejezetten a zongoratanulás kezdeti éveire szánt, máig a zongoraoktatás egyik legértékesebb alapműve. A Gyermekeknek első és második kötetének öt gyermekdal feldolgozása Forrai Katalin Ének az óvodában című könyvében is fellelhető. Ezek a könnyen énekelhető, játékkal összekapcsolható énekek az óvodai énekes repertoár fontos részét képezik. Bartók a népzenét természeti jelenségnek tekintette és a nagy müvészetek alkotásaival egyenrangú, tökéletes művészetként értékelte. A kisgyermekkori zenei nevelésben ezek az eszmék a magyar zenei nyelv elsajátításán és élményszerü befogadásán keresztül valósulhatnak meg.
\end{abstract}

Kulcsszavak: népzene, zongoramü, 20. századi zene, magyar zenei nyelv

\section{Bartók és a népzene}

15 évvel ezelőtt, amikor Bartók születésének 125. évfordulójáról emlékeztünk meg, Tallián Tibor ${ }^{1}$ zenetörténész e szavakkal írt Bartók és a magyar kultúra kapcsolatáról: „Bartók Béla muzsikus létére nemcsak a magyar zene és művészet, hanem egyre növekvő mértékben a magyar nyelv, és ezen keresztül az egész kulturális közösségünk legmesszebbre hangzó szavú és legnagyobb hitelü szószólója a külvilágban." (Tallián, 2006).

2021-ben, születésének 140. évét ünnepelve bátran kijelenthetjük, hogy Bartók méltán a 20. század egyik legismertebb zeneszerzője, népzenetudósa és zongoraművésze. De ez nem volt mindig magától értetődő; az 1900-as

\footnotetext{
${ }^{1}$ Tallián Tibor (1946-) Széchenyi- és Erkel Ferenc díjas zenetörténész, zenekritikus és egyetemi oktató. Tudományos tevékenysége különösen Bartók Béla életművére, a 20. századi zenére, illetve a magyar operatörténet kutatására irányul.
} 
évek közönségének évtizedekbe tellett, amíg megtanulta elfogadni és értékelni Bartók zenéjét és abban a paraszti népzene magyarságának gyökereit. Ő maga többször kifejtette, hogy mi indította el azon az úton, mely a magyar népzene feltárása és saját zenéjének megújítási programja felé vezette: „személyes és nemzeti önazonosság új tartalmainak keresése" határozta meg a korai évek útkeresését. Bartók érdeklődése nagyjából egy időben támadt fel a magyar, szlovák és román népzene felé.

Az I. világháború előtt hatalmas népzenei gyűjtemények keletkeztek, melyek később megújult zeneszerzői programjának állandó inspirációs forrását jelentették. Népzenei ismereteit később folyamatosan bővítette; 1934-ben Bukarestben román népzenei felvételeket tanulmányozott, az Egyesült Államokban szerb és horvát népdalokat jegyzett le, valamint arab és török népzenét is mélyrehatóan elemzett. Bartók saját nemzete népzenéjének határait átlépve, más népek zenéjét megismerve az összehasonlítás módszerének tudományos alkalmazásával egy új korszakot hozott létre. Az 1900-as években megfogalmazott céljait - kimutatni a magyarság zenéjének megkülönböztető jegyeit - hosszú, négy évtizedes népzenekutatói pályája során nem tévesztette szem elől. Zeneszerzői életműve és a népzenei tanulmányutak tapasztalatait így fogalmazta meg az 1930-as években:

„Igazi eszményem azonban, melynek zeneszerzői magamra találásom óta tökéletesen tudatában vagyok, a népek testvérré válása, minden háború és viszály ellenére. Amennyire erőim engedik, ezt az ideát szolgálom zenémben; ezért nem vonom ki magam semmiféle hatás alól, eredjen bár szlovák, román, arab vagy bármi más forrásból - csak legyen a forrás tiszta, friss és egészséges!" (Tallián, 2006)

\section{A népzenegyűjtés kezdetei (1904-1908)}

1904-ben az ifjú, 23 éves Bartók korai életválságából kiutat keresve az északmagyarországi Gömör megyében, Gerlicepusztán nyári remeteségbe vonult. A természet és az ősi kelet-európai paraszti életmód ott ekkor még majdnem érintetlen volt. Szokása szerint sokat sétált, láthatta és főleg hallhatta az évszázados paraszti lét megnyilvánulásait. Harminc évvel később így emlékezett vissza a népdallal történő első találkozásra:

„Öszintén bevallom, egészen 23 éves koromig azt hittem [...] csakis ez a fajta magyar népdal (a nóta) van a világon. Akkor azonban - 1904-ben kezdtem ráunni erre a túlontúl ismert anyagra. Gondolkodóba estem: vajon csakugyan nincs-e több magyar népdal a világon? Vajon nem tudnak-e a falusi egyszerủ emberek olyan nótákat, amiket mi városiak nem is ismerünk. Egy véletlenül kínálkozó alkalmat felhasználva próbaképpen meghallgattam egy székely falusi lányt, Dósa Lidit. Lejegyeztem éneke nyomán egyszeribe 5-6 dalt, csupa ösmeretlen dallamot, és ami még fontosabb, olyan dallamokat, amelyek teljesen elütöttek az ismert városi magyar nóta-típusoktól. Ez 
az első kísérlet határtalan lehetőségek felé mutatott utat: elhatároztam, hogy rálépek erre az útra, kellő előkészület után." (Tallián, 1979, p. 42).

A népzenegyűjtés módszerét Kodálytól tanulta, aki 1905-ben védte meg doktori értekezését $A$ magyar népdal strófaszerkezete címmel. Első közös céljuk a művelt közönségnek szóló népszerű dalkiadvány összeállítása volt. Ennek eredményeképpen 1906 végén jelent meg Bartók és Kodály közös feldolgozásában az első magyar parasztdalgyüjtemény Magyar népdalok énekhangra zongorakísérettel. A népdalok ihlette remekművek egész életművét végigkísérik. Bartóknak minden harmadik kompozíciója népdalfeldolgozás, vagy legalábbis tartalmaz népdal-témájú tételt. 1904-ből származnak az első népdallejegyzések és halála előtt néhány hónappal írta utolsó népdalfeldolgozását.

Még mielőtt teljesen elhatárolódott volna a városi társaságtól és életviteltől, Mihalovich Ödön, a Zeneakadémia tekintélyes igazgatója, 1907 elején kinevezte Bartókot a Zeneakadémia zongoratanszékére tanárának. Bartók sosem rejtette véka alá, hogy a tanítást nyügös robotnak érzi, mégis elfogadta az ajánlatot, mely - mint az Önéletrajzban írta - „lehetővé tette, hogy itthon telepedjem le és így tovább haladjak folklorisztikus céljaim felé" (Tallián, 2016, p. 101).

\section{Korai zongoramúvek (1908-1911)}

A következő években, 1908-1911 között keletkeztek Bartók korai zongoraművei. 1908-ban megdöbbentő határozottsággal lépett Bartók a zenei avantgarde élvonalába. E lépés következtében innentől kezdve az európai új zene legfontosabb személyiségei közé tartozott. Zongoradarabjainak egyéni arculata ekkor kezdett kibontakozni, merészen szembeszállt a stílusbeli és kompozíciós dogmákkal. Ez különösen a legkorábbi sorozatban, a Tizennégy bagatellben mutatkozott meg: hátat fordított a jól felépített zenei formáknak, a régi hangnemiségnek és a karakterdarabok világának. 1945-ben így nyilatkozott róluk Amerikában:

„Ezekben az új zongorastílus jelentkezik ellenhatásként a 19. század romantikus zongorazenéjének túláradására; e stílus lemond minden lényeghez nem tartozó dekoratív elemről és szándékosan csak a legszükségesebb technikai eszközöket alkalmazza. Amint későbbi fejlemények mutatják, a Bagatellek a zongorastílus új irányát kezdeményezik pályámon, amelyet majdnem valamennyi későbbi zongoraművem következetesen folytat, kisebb-nagyobb módosításokkal." (Tallián, 1950, p. 94).

Bartók már az 1910-es évek óta ismert komponista volt, ismertsége azonban csak a modern müvészet híveinek szük körében jelentett elfogadottságot. Az átlagos zenehallgatók ekkor idegenkedéssel fogadták műveit. Bartók többször kifejtette, hogy mi indította el a paraszti népzene megismeréséhez és saját zenéjének a népzene szellemében való megújításához. A népzenét a 
nagy művészetek alkotásaival egyenrangú, tökéletes művészetként értékelte. A népzenét természeti jelenségnek tekintette, ezért minden tartalom, amit a népzenében felfedezett, számára mélyebb, ösztönszerübb és általánosabb jelentést is hordozott.

A Bagatellek 1908 májusában készen voltak, a Tíz zongoradarab júniusban került ki Bartók tolla alól. Következő sorozatának, a Vázlatok harmadik tételét Kodálynak és feleségének ajánlotta. E ciklus korábbi, 1908-ból való egyik darabjának ajánlása pedig Ziegler Mártáé, akit 1908 szeptembere óta ismert és tanított. Személyében őt megértő, érzékeny, gondolataira fogékony, tökéletesen odaadó társat ismert meg. Házasságkötésük 1909-ben történt, majd egy évvel később, 1910 augusztusában megszületett fiuk, ifjú Bartók Béla.

A korai mủvek új zenei típussal-karakterrel kísérletező ciklikus művei továbbá a Három burleszk, a Két román tánc és a Négy sirató ének. A zeneszerzői korszak záróköve Bartók emblematikus műve, az 1911-ben komponált Allegro barbaro. Ebben a müben figyelemre méltóan hangolja össze saját egyéniségét a zongora elsősorban ütőhangszerszerü kezelésével, melyben a ritmus magával ragadó ereje elhomályosítja a dallamot.

\section{A Gyermekeknek sorozat}

Az 1905-től gyüjtött, vagy régebbi gyűjteményekben megismert magyar és szlovák népdalok közönség után kiáltottak. Ezzel a céllal írta nagyszabású népdalfeldolgozás-gyüjteményét, az 1908-1909-ben készült Gyermekeknek címü sorozatot. Bartók népzenei munkássága mellett hivatásos zongoristaés zenepedagógusi tevékenységet is folytatott, így a szélesebb társadalmi rétegek zenei műveltségének befolyásolása végett a népzene terjesztését többek között a gyermekek számára készített hangszeres művekkel tudta elérni. A zongoragyűjtemény négy füzetből áll, valamennyi darabja gyermek-, illetve népdalfeldolgozás. Az első kiadás röviddel a keletkezés után jelent meg Rozsnyai Károly kiadásában. Ebben az első két füzet összesen 42 magyar népdalra komponált rövid zongoraművet, a harmadik és negyedik füzetek 43 szlovák népdalon alapuló darabot tartalmaztak.

A sorozat átdolgozott változatát Bartók több mint 30 évvel később, 1943ban, az Egyesült Államokban készítette el a Boosey \& Hawkes kiadó számára. Az átdolgozás mértéke minimális volt, szándékosan kimaradt két magyar és négy szlovák népdal. Ennek az a magyarázata, hogy Bartók négy darabnál nem volt biztos a népdal valódi eredetében, két szlovák dalt pedig nem ö, hanem Kodály Zoltánné Gruber Emma dolgozott fel zongorára. A darabok első kiadása minden kötet végén jegyzeteket tartalmazott, ahol a felhasznált dalok szövegeit tüntették fel. Ezért ebben a kiadásban Bartók nem adott címeket a magyar népdalokon alapuló daraboknak; a harmadik és negyedik füzetben található szlovák dalok szövegének németre fordítását szintén Kodály Zoltánné készítette. Az 1943-ban elkészült második kiadásra már a szerző 
halála után, 1946-ban került sor. Ebben a kiadásban Bartók néhány darabhoz címet illesztett, mivel abban már nem kerültek közlésre a magyar népdalok szövegei. Az a tény, hogy a zeneszerző látta-e nyomtatás előtt az utolsó levonatot, sajnos, nem derült ki.

Bartók fontosnak tartotta, hogy már a zongoratanulás első éveiben értékes művekkel ismerkedhessenek meg a tanulók. Így nyilatkozott erről: „had' jussanak a tanulók a tanulás első egynéhány évében olyan előadási művekhez, amelyekben a népi zene keresetlen egyszerüsége annak dallambeli és ritmusbeli különösségével együtt megvan." (Ujfalussy, 1976, p. 363).

A Gyermekeknek sorozat a zongoraoktatás egyik alapműve, a világon szinte mindenhol tanulnak belőle. Az első füzet 21 darabja rövid terjedelmü, de a számok növekedésével fokozatosan nehezedik. Mindegyik egy népdal, ritkábban gyermekdal feldolgozása. A második füzet további 19 magyar népdal feldolgozását tartalmazza. Záródarabja, a Kanásztánc, szélsőséges dinamikai hangzásaival és gyors tempójával alapos hangszeres technikai felkészültséget kíván az előadótól. Amint korábban említettem, a harmadik és negyedik füzet szlovák népdalok feldolgozásának gyüjteménye, amelyben 22, illetve 17 miniatür zongoradarab található.

A népdalfeldolgozásokban az eredeti dallam többnyire egyben marad, közérthetően, könnyen énekelhető formában hangzik el. Bartók jellemzően közjátékokkal szakította meg, vagy a basszusba helyezte a dallamot. Ezekbe a zongorafeldolgozásokba tömöríti a népi zene, paraszti érzelemvilág iránt lelkében ébredt gyengéd szeretetet. A művek oldott, természetes közlékenységgel szólnak a korai zongoraművek termésében.

\section{Bartók Béla gyermek- és népdalfeldolgozásai az óvodai énekes repertoárban}

A Gyermekeknek sorozat első és második kötetének néhány nép-, illetve gyermekdal szövege és dallama megtalálható Forrai Katalin Enek az óvodában címü könyvében: Süssünk, süssünk valamit; Süss fel, nap; Elvesztettem páromat; Kis kece lányom; Anyám, édes anyám. Ezek a könnyen énekelhető, többnyire játékkal párosítható gyermekdalok az óvodai zenei nevelés repertoárjának fontos részét képzik. Az óvodai zenei anyag énekesjátékai a magyar gyermekjáték-hagyományból származnak.

Kiss Áron Magyar gyermekjáték gyüjteményében található meg a Süss fel, nap; és az Elvesztettem páromat. Az 1891-ben megjelent mü gazdag tárháza a 19. század végi gyermek- és játékdaloknak, bő egy évtizeddel korábban Kodály és Bartók első népdalgyűjtő útja előtt. A másik két gyermekdal - Süssünk, süssünk valamit; Kis kece lányom - gyűjtőhelye Gyergyóújfalu és a Tolna megyei Felsőiregh. Az Anyám, édes anyám pedig Gyergyócsomafalváról származik.

A Gyermekeknek első kötet nyitódarabja a Játszó gyermekek. Szövege a kottában: 
„Süssünk, süssünk valamit,

Azt is megmondom, hogy mit;

Lisztből legyen kerekes,

Töltelékes, jó édes.

- Sodorva, tekerve,

Turóval bélelve,

Csigabiga rétes,

Kerekes és édes †”

(Gyermekdal, Gyergyóújfalu)

A gyermekdal Forrai Katalin könyvében rövidebb szöveggel, 8 ütemben van lejegyezve:

„Süssünk, süssünk valamit,

azt is megmondom, hogy mit.

Rétest, bélest,

túrósat és édest."

Játékmódja kanyarodó lánc. A gyerekek sorban állnak, majd az éneklésre a sor láncban elindul, kanyarodik, rétest kerekít be és ki. Amikor az „édes” szót éneklik, a gyerekek leguggolnak, majd folytatják a játékot. Bartók feldolgozásában könnyed karakterü mü született: a kétvonalas oktávban megszólaló dallamnak egy oktávval mélyebben szól a kísérete. A dal kétszer hangzik el, a légies semplice, egyszerü melódiával és a legato-staccato billentésmóddal bájos, gyermeki hangzás szólal meg².

Az első kötet 2. darabja a Gyermekdal címet kapta, szövege a kotta jegyzeteiben a következő:

„Süss fel, nap,

Szent György nap,

Kertek alatt a kis bárány

Majd megfagy."

(Kiss Áron: Magyar Gyermekjáték-gyüjtemény, p. 23)

Ugyanennek a dalnak a szövege Forrai Katalin könyvében:

„Süss fel, nap,

Fényes nap,

Kertek alatt kis ludaim

megfagynak."

${ }^{2}$ Ahogy az az alábbi hanganyagban hallható: Bartók: Gyermekeknek 1. kötet: Játszó gyermekek (Süssünk, süssünk valamit) https://www.youtube.com/watch?v=nXZH5KhrOPY 
A tavaszváró dallal a gyerekek éneklés közben a napot csalogatják ki. Bartók zongoraművében a gyermekdal háromszor hangzik el változó, egyszerü harmóniákkal alátámasztva. A C-dúr tonalitást alterált hangok - Cisz és B teszik változatossá. A dinamika piano és pianissimo hangzásai a gyermekdal szövegét érzékeny módon ábrázolják ${ }^{3}$.

A 3. darab az Elvesztettem páromat kezdetü dal feldolgozása. Bartók moll-jellegü, a Fisz hanggal kiegészített dór hangsorban komponálta a feldolgozást. A dal kétszer szólal meg, amit majdnem végig egy tiszta kvint-nagy terc kettősfogás kísér. Ezt a monoton kíséretet csupán a 16-17. ütemekben töri meg egy kis szeptim-nagy terc hangköz kapcsolat. Ennek a cím nélküli dalnak a szövege majdnem teljesen megegyezik a két helyen, csupán annyi a változás, hogy a Forrai könyvben a „Gyer” helyett „Jer” szerepel:

„Elvesztettem páromat,

Szép eladó lányomat.

Gyer haza, lányom,

Lidi nevü lányom."

(Kiss Áron:Magyar. Gyermekjáték-gyüjtemény, p 186)

A dal játéka sorgyarapodó. A gyerekek körben állnak, egy közülük a körön kívül jár. A „Jer haza” résznél a gyermek megérinti egy társa hátát, akinek a nevét behelyettesítik a dalba. A megnevezett a hívóhoz csatlakozik és a játék addig tart, amíg a körből mindenkit elhívnak ${ }^{4}$.

A Körtánc az első kötet 17. darabja, a Kis kece lányom kezdetű dal feldolgozása. A Gyermekeknek 1. kötet egyik legszebb lírai darabja, melyben a kezdő zongoristák a pedálozás technikáját is gyakorolhatják. A mü karakterét súlyos disszonanciák, alterált hangokkal felépített akkordok, orgonapont és lassú, lento tempó ábrázolják. A kottában olvasható szöveg:

„Kis kece lányom fehérbe vagyon

Fehérbe, rózsám, fehérbe vagyon.

| Mondom, mondom, fordulj hozzám,

mátkám asszony. †”

(Gyermekdal Felsőireghről, Tolna megye)

Forrai Katalin könyvében található dalszöveg:

${ }^{3}$ Ahogyan az az alábbi hanganyagban hallható: Bartók, B.(2020). Gyermekeknek zongorára I. : Gyermekdal (Süss fel, nap).Editio Musica Budapest. https://www.youtube.com/ watch?v=JTB_rANI4SQ

${ }^{4}$ Ahogyazazalábbi hanganyagban hallható: Bartók, B. (2020). Gyermekeknekzongorára I.: (Elvesztettem páromat). Editio Musica Budapest. https://www.youtube.com/watch?v=ubm9VXL5cxw 
„Kis kece lányom, fehérbe vagyon.

Fehér a rózsa, kezébe vagyon.

Mondom, mondom, fordulj ide mátkám asszony,

Mondom, mondom, fordulj ide mátkám asszony."

Bartók zongoraműve komor hangulatú, de énekelve tánchoz illeszthetjük ezt a lakodalmas dalt, melyet a gyerekek életkorának megfelelő koreográfiával érdemes betanítani ${ }^{5}$.

Végül a Gyermekeknek 2. kötet 8. darabja, az Ötfokú dallam címü darab szövege olvasható alább, amelyben Bartók az Anyám, édesanyám kezdetü népdalt dolgozta fel:

„Anyám, édes anyám,

Elfeslett a csizmám.

Elfeslett a csizmám,

Ki varrja be immán?”

(Gyergyócsomafalva)

Bartók sziporkázó, vidám hangulatú feldolgozását hallhatjuk, tele friss zenei ötletekkel. Annak ellenére, hogy a népdal végig a bal kézben van, mégis könnyed a zenemü karaktere. Rövid staccato billentés, sok váratlan hangsúly, regiszterváltások és tempóingadozások teszik incselkedővé ezt a komolyabb pianisztikus felkészültséget igénylő kis remekmüvet.

A népdal éneklését a kezdő szöveg - Anyám, édesanyám - miatt anyák napján javasolják az óvodai ünnepkörben 6 .

A fenti példákból láthatjuk, hogy a magyar gyermek- és népdalfeldolgozások szorosan összefonódnak a hangszeres és az óvodai énekes repertoárban. Az óvodai zenei nevelés során mindegyik kiválóan alkalmas a magyar népzene és a kultúra továbbörökítésére. A népdalok éneklése, a gyermekjátékok eljátszása és a hangszeres zene befogadása olyan élményekkel gazdagíthatja az óvodás korú gyermekeket, melyek egy életre meghatározóak lehetnek számukra.

\section{Irodalom}

Bartók, B. (2020). Gyermekeknek zongorára I-II, Editio Musica Budapest.

Forrai, K. (2016, 2017). Ének az óvodában. Móra Kiadó.

Lampert, V. (1980). Bartók népdalfeldolgozásainak forrásjegyzéke. Zenemükiadó.

\footnotetext{
${ }^{5}$ Ahogyan az az alábbi hanganyagban hallható: Bartók, B. (2020). Gyermekeknek 1. : Körtánc (Kis kece lányom). Editio Musica Budapest. https://www.youtube.com/watch?v=Sm-2veeITJ8 ${ }^{6}$ Ahogyan az az alábbi hanganyagban hallható: Bartók, B. Gyermekeknek zongorára II. : Ötfokú dallam (Anyám, édes anyám). Editio Musica Budapest. https://www.youtube.com/ watch?v=eubPZ_OXJXA
} 
Matthews, D. (1976). Zongoramuzsika kalauz. Zenemúkiadó.

Tallián Tibor (1950, közr.). Bartók Béla írásai 1. Zenemúkiadó.

Tallián, T. (1979). Bartók-marginália. In Berlász, M. \& Domokos, M. (Eds.), Zenetudományi dolgozatok (pp. 35-46). MTA Zenetudományi Intézet.

Tallián, T. (2006). Bartók 125 évfordulóra. Muzsika, 49(3), 3.

Tallián, T. (2016). Bartók Béla. Rózsavölgyi és Társa.

Ujfalussy, J. (1976). Bartók breviárium. Gondolat Kiadó. 


\section{Szesztay, Zs.}

\section{Hungarian children's and folk song arrangements in the collection For Children by Béla Bartók}

This study is dedicated to Béla Bartók (1881-1945), one of the most significant composers, folk music theorists and pianists of the twentieth century, on the 140th anniversary of his birth. Collections of Hungarian folksongs and children's song were a particularly important source of inspiration for Bartók in those of his early works for piano composed between 1908 and 1911. Among these the four volumes of For Children from 1908-1909 play an especially significant role. Bartók, as pianist and music teacher, intended this cycle for the beginning years of the study of piano, and as such it remains an invaluable fundamental work. Five children's song-based works from the first and the second volumes of For Children can be also found in Katalin Forrai's book Singing in Preschool. These works are easy to sing and to relate to games, and thus they are among the key pieces of standard preschool song collections. Bartók regarded folk music as a phenomenon of natural origin and treated it as valuable and as perfect as the masterpieces of the greatest composers. In the musical education of young children these principles can be appreciated through the enjoyable experience and accomplishment of Hungarian musical language.

Keywords: folk music, piano work, music of the 20th century, Hungarian musical language

Szesztay Zsuzsa: http://orcid.org/0000-0001-8372-1732 